\title{
INVESTIGATION OF OCCUPATIONAL MORBIDITY IN WOOD PROCESSING INDUSTRY IN COMPARISON WITH OTHER MANUFACTURING INDUSTRIES AND WITH OCCUPATIONAL MORBIDITY IN LATVIA AT LARGE
}

\author{
Maija Eglīte*, Ivars Vanadziṇš ${ }^{*}$, Jeḷena Reste**, Elvīra Čurbakova**, Jolanta Cīrule**, \\ and Sigita Ķeire ${ }^{\star *}$ \\ * Institute of Occupational Safety and Environmental Health, Rīga Stradiṇš University, Dzirciema iela 16, Rīga, LV-1007, LATVIA \\ E-mail: Maija.Eglite@rsu.Iv \\ * Center of Occupational and Radiological Medicine, Pauls Stradinš Clinical University Hospital, Pilsoṇu iela 13, Rīga, LV-1002, LATVIA
}

Communicated by Andrejs Skaǵers

\begin{abstract}
The aim of the study was to investigate occupational morbidity in the wood processing industry to gain understanding of the real situation of occupational health and to improve the diagnostics of occupational diseases. The occupational morbidity in Latvia has gradually increased from 1993 to 2004, with a slight decrease in 2005 and 2006 followed by an increase in 2007. In the year 2004, the number of first-time occupational diseases patients exceeded the number of occupational diseases patients registered in the year 1993 by 9.5, but the number of registered first-time incidences of occupational diseases in comparison with 1993 had increased by 14.5 times. In the manufacturing industry, wood and cork production, a trend of increasing rate of occupational diseases can also be observed in Latvia. A particularly rapid increase was observed in specific illnesses related to the musculoskeletal and connective tissue system, carpal tunnel syndrome as well as to occupational hearing loss, which might be explained by changes in the occupational risk factors. Despite an increase in the total number of occupational diseases in the industry of wood and cork products over the whole study period, these industries have lower levels of occupational diseases in comparison with occupational morbidity in such fields as health and social care, the extraction industry and quarry management, transportation and transport services, communications and telecommunications. In developed European Union countries, over the last few years, the number of occupational diseases has decreased, while there has been an increasing trend in Latvia. This can be explained by the fact that the working conditions in the European Union have been improving over the last few decades, and correspondingly the number of occupational diseases is decreasing. However, in Latvia, the diagnostics of the occupational diseases is rapidly improving, while improvement of working conditions has started relatively recently. Furthermore, the process has not been rapid, and therefore, results could be expected only in the future.
\end{abstract}

Key words: wood processing industry, occupational morbidity, Latvia, structure of occupational diseases.

\section{INTRODUCTION}

Wood is one of the most important renewable natural resources of the world. Forests take up approximately $1 / 3$ of the total area of the globe, and half of this treasure is used for manufacture of various wood materials. In European Union countries, approximately 3.6 million people are employed in the wood processing industry (Kauppinen et al., 2006). The term "wood-processing", in a capacity of an industry, comprises companies, which in accordance with the internationally standardised classification of economic activities (Nomenclature des activites economiques des
Communautes Europeennes, Classification of Economic Activities in the European Community - NACE) are involved in the following industries:

- DD20 - production of wood and cork goods, excluding furniture; straw goods and wicker-works, and

- DN36 - furniture manufacturing, production that is not classified elsewhere.

The NACE version, which was valid until 31 December 2007, was used in the work. 
The majority of employees of the wood processing industry are simultaneously subjected to effects of several risk factors - dust, noise, vibrations, unbeneficial microclimatic conditions, chemical substances, biological, ergonomical, psycho-emotional and organisational factors (Innos et al., 2000; Kal,kis et al., 2000; Mandryk et al., 2000; Mikkelson et al., 2002; Vanadziňš et al., 2003; Priha et al., 2004; Kauppinen et al., 2006; Martinsone et al., 2006; Schlunssen et al., 2008). Risk factors influencing wood processing workers have been globally studied to a large extent. Other risk factors have not been considered as much. The available literature includes few studies devoted specifically to studies of occupational diseases and the occupational illness rate of those employed in wood processing. In the wood processing industry, the influence of the risk factors of the working environment on health condition of the employed and development of the occupational diseases is not sufficiently well recognised, and a significant part of the occupational diseases is not diagnosed or the diseases are diagnosed too late.

According to the Law on Compulsory Social Insurance in Respect to Accidents at Work and Occupational Diseases (adopted on 2 November 1995, in force from 1 January 1997) the term "occupational disease" is defined as follows: "Occupational diseases are diseases characteristic to certain categories of employees, which are caused by physical, chemical, hygienic, biological and psychological factors in the working environment."

In Latvia occupational diseases are diagnosed and coded according to the International Classification of Diseases; corresponding codes are indicated in brackets after the name of a disease or a group of diseases.

Over the last 15 years, a rapid total increase of the occupational illness rate was observed in Latvia, but the rate in the field of wood processing industry was among the lowest in Latvia, and was significantly lower than the indices of the European Union countries. On very rare occasions, acute or sub-acute cases of occupational diseases or chronic occupational diseases in the initial stages have been recorded. The low occupational illness rate amongst those employed in wood processing might be explained by insufficient extensive or systematic studies on health of the employed in wood processing in Latvia. Therefore, there is a need not only for a scientifically substantiated study of risk factors of the working environment in the wood processing industry, but also for evaluation of the health condition of the employed, using modern examination methods, and establishing correlations between the risk factors of the working environment and health indices. This would allow to prevent difficult, irreversible diseases, which at this time have not been observed to be associated with the working environment.

The aim of the study was to investigate occupational morbidity in wood processing industry to gain understanding of the real situation of occupational health and to improve the diagnostics of occupational diseases.
The objectives were:

1) to study occupational morbidity in the wood processing industry, analyse the data dynamically in comparison with the country in general and with other manufacturing industries;

2) to analyse the structure of occupational diseases in a temporal context;

3) to compare occupational morbidity in Latvia with the situation in other European countries.

\section{MATERIALS AND METHODS}

The analysis of occupational diseases was performed from 1993 to 2007, using the data of the register of Latvian State Occupational Diseases Patients and of persons subjected to effects of radiation as a result of consequences of the catastrophe of the Chernobyl nuclear power plant. The said register is available at the Occupational and Radiological Medicine Centre of Pauls Stradiņš Clinical University Hospital. Currently, the final diagnosis of occupational diseases in Latvia is determined by the Consultative Commission in Occupational Diseases, consisting of doctors of the Centre (in accordance with the Regulations No. 908 of the Cabinet of Ministers (CM) of the Republic of Latvia (RL) "Procedure of examination and registering occupational diseases", adopted on 6 November 2006).

Diagnosis of occupational diseases in Latvia is established and coded according to the international classification of diseases. Currently, the used classification in Latvia is the $43^{\text {rd }}$ International Statistical Classification of Diseases and Related Health Problems (ISC-10), according to Regulation No. 20 of 17 January 1996 of the Ministry for Welfare of the Republic of Latvia. This classification has been adopted in Latvia without modification, which allows for comparison between countries.

The analysed data included the absolute initially registered number of occupational diseases patients, as well as the absolute number of initially registered occupational diseases. In order to characterise the rate of cases of occupational diseases in dynamics, the illness incidence rate (IR) was used. IR was the number of persons suffering from occupational diseases as a first time occurrence within one year per 100000 of the employed in Latvia at the beginning of the year.

The occupational morbidity was analysed in Latvia in general, in the wood and cork production industries, in comparison with other manufacturing industries, in the time period from 1993 till 2005.

\section{RESULTS}

According to the data of Latvian State Occupational Diseases Patients Registry, in Latvia during 1993 to 2007, 5512 new occupational diseases patients (first-time patients) were 
registered: 2547 male and 2938 female patients (Table 1). Among these occupational diseases patients, there were a total of 12484 first-time registered occupational diseases: 5545 for male patients, and 6907 for female patients (Table 2).

During 1995-2005, each occupational diseases patient had on average 2.36 occupational diseases; male patients had 2.28 and female patients 2.43 occupational diseases. This suggests different effects of harmful occupational factors on each employee, which can occur simultaneously or at different time periods.
The number of first-time registered occupational diseases patients, as well as the number of occurrences of occupational diseases has gradually increased from 1993 to 2004, but in 2005 there was a slight decrease in the number of registered occupational diseases patients and occupational diseases, which continued also in the year 2006. In 2007, the number of first-time occupational diseases patients and occurrences of occupational diseases again increased. The number of first-time diagnosed occupational diseases patients exceeded the number of occupational diseases patients registered in the year 1993 by 9.5 times, and the

Table 1

TOTAL NUMBER OF FIRST-TIME REGISTERED OCCUPATIONAL DISEASES PATIENTS IN LATVIA DURING 1993-2007 (BY YEAR AND GENDER)

\begin{tabular}{|c|c|c|c|c|c|c|}
\hline \multirow[t]{2}{*}{ Year } & \multicolumn{2}{|c|}{ Total } & \multicolumn{2}{|c|}{ Males } & \multicolumn{2}{|c|}{ Females } \\
\hline & absolute number & $\begin{array}{c}\text { incidence per } 100000 \\
\text { employed persons }\end{array}$ & absolute number & $\begin{array}{c}\text { incidence per } 100000 \\
\text { employed males }\end{array}$ & absolute number & $\begin{array}{c}\text { incidence per } 100000 \\
\text { employed females }\end{array}$ \\
\hline 1993 & 82 & - & 43 & - & 39 & - \\
\hline 1994 & 185 & - & 72 & - & 113 & - \\
\hline 1995 & 174 & - & 96 & - & 78 & - \\
\hline 1996 & 109 & 11.5 & 55 & 11.1 & 54 & 11.9 \\
\hline 1997 & 118 & 11.9 & 77 & 15.2 & 41 & 8.5 \\
\hline 1998 & 149 & 15.1 & 75 & 14.6 & 74 & 15.6 \\
\hline 1999 & 211 & 23.1 & 108 & 21.5 & 103 & 22.1 \\
\hline 2000 & 232 & 25.5 & 105 & 21.9 & 127 & 27.5 \\
\hline 2001 & 332 & 35.5 & 150 & 30.9 & 182 & 38.2 \\
\hline 2002 & 433 & 45.9 & 181 & 35.8 & 252 & 52.1 \\
\hline 2003 & 554 & 56.9 & 235 & 45.5 & 319 & 65.1 \\
\hline 2004 & 786 & 78.5 & 343 & 65.7 & 443 & 89.3 \\
\hline 2005 & 782 & 75.1 & 370 & 71.7 & 412 & 84.5 \\
\hline 2006 & 589 & 54.2 & 293 & 52.4 & 296 & 56.0 \\
\hline 2007 & 776 & 69.3 & 371 & 64.7 & 405 & 74.2 \\
\hline Total & 5512 & & 2574 & & 2938 & \\
\hline
\end{tabular}

Table 2

TOTAL NUMBER OF FIRST-TIME REGISTERED OCCUPATIONAL DISEASES DURING 1993-2007

\begin{tabular}{|c|c|c|c|c|c|c|}
\hline \multirow[t]{2}{*}{ Year } & \multicolumn{2}{|c|}{ Total } & \multicolumn{2}{|c|}{ Males } & \multicolumn{2}{|c|}{ Females } \\
\hline & absolute number & $\begin{array}{c}\text { incidence per } 100000 \\
\text { employed persons }\end{array}$ & absolute number & $\begin{array}{c}\text { incidence per } 100000 \\
\text { employed males }\end{array}$ & absolute number & $\begin{array}{c}\text { incidence per } 100000 \\
\text { employed females }\end{array}$ \\
\hline 1993 & 127 & - & 76 & - & 51 & - \\
\hline 1994 & 284 & - & 110 & - & 174 & - \\
\hline 1995 & 311 & - & 180 & - & 131 & - \\
\hline 1996 & 194 & 20.4 & 94 & 19.0 & 100 & 22.0 \\
\hline 1997 & 260 & 26.3 & 179 & 35.2 & 81 & 16.8 \\
\hline 1998 & 346 & 35.1 & 196 & 38.3 & 150 & 31.6 \\
\hline 1999 & 434 & 47.5 & 223 & 44.3 & 211 & 45.3 \\
\hline 2000 & 760 & 83.6 & 344 & 71.7 & 416 & 90.2 \\
\hline 2001 & 891 & 95.4 & 392 & 80.7 & 499 & 104.8 \\
\hline 2002 & 1150 & 121.9 & 483 & 95.6 & 667 & 137.8 \\
\hline 2003 & 1520 & 156.2 & 601 & 116.2 & 919 & 187.6 \\
\hline 2004 & 1847 & 184.5 & 750 & 143.7 & 1097 & 221.2 \\
\hline 2005 & 1693 & 162.7 & 734 & 142.2 & 959 & 196.7 \\
\hline 2006 & 1076 & 98.9 & 482 & 86.2 & 594 & 112.4 \\
\hline 2007 & 1559 & 139.3 & 701 & 122.2 & 858 & 157.3 \\
\hline Total & 12452 & & 5545 & & 6907 & \\
\hline
\end{tabular}


number of first-time registered occupational diseases in comparison with 1993 had increased by 14.5 times in 2004 .

Figure 1 shows the dynamics of morbidity with occupational diseases in the wood and cork production industries (NACE D20+D36). The number of first-time registered cases of occupational diseases in comparison with 2002 had increased by 2.1 times in the year 2005 .

Figure 2 shows the structure of the most frequent cases of occupational diseases in the wood and cork production industries from 1993 to 2005 per 100000 employees. In the country in general, and in the wood and cork industry, the number of occurrences of musculoskeletal and connective tissue disorders increased most rapidly, in particular those related to vertebral spondylosis with radiculopathy. Carpal tunnel syndrome took the second position in the number of occurrences. Over the last two analysed years, a rapid increase in the number of vibration related illnesses was observed, but over the past three years, in the cases of noise effects on the inner ear. The occurrence of chronic obstructive pulmonary diseases in 2005 was lower than in 2001 .

By comparing the rate of occurrence of occupational diseases in various industries per 100000 employees over the period from 2002 to 2005 , the industry of production of wood and cork goods showed the lowest levels of occupational diseases (Table 3, Fig. 3). In 2005, it was almost three times lower than in the fields of health and social care, extraction industry, and quarry management; 2.5 times lower than in the fields of transportation, transport services, communications and telecommunications, and twice lower than in fishing.

\section{DISCUSSION}

In order to evaluate objectively how various and very serious risk factors of the working environment in the wood processing industry influence health of the employees, the rate of occupational diseases in Latvia in general and in wood processing and joinery was compared with that in other manufacturing industries. The study analysed also the problem of labour safety and health problems of those employed around the world. In European Union countries in 2006, the cases of occupational diseases and accidents at work reached around 10 million (Smedley et al., 2007). The importance of the problem is well substantiated by the following facts:

- every seventh employee has a diagnosed case of occupational disease or has suffered in an accident at the workplace;
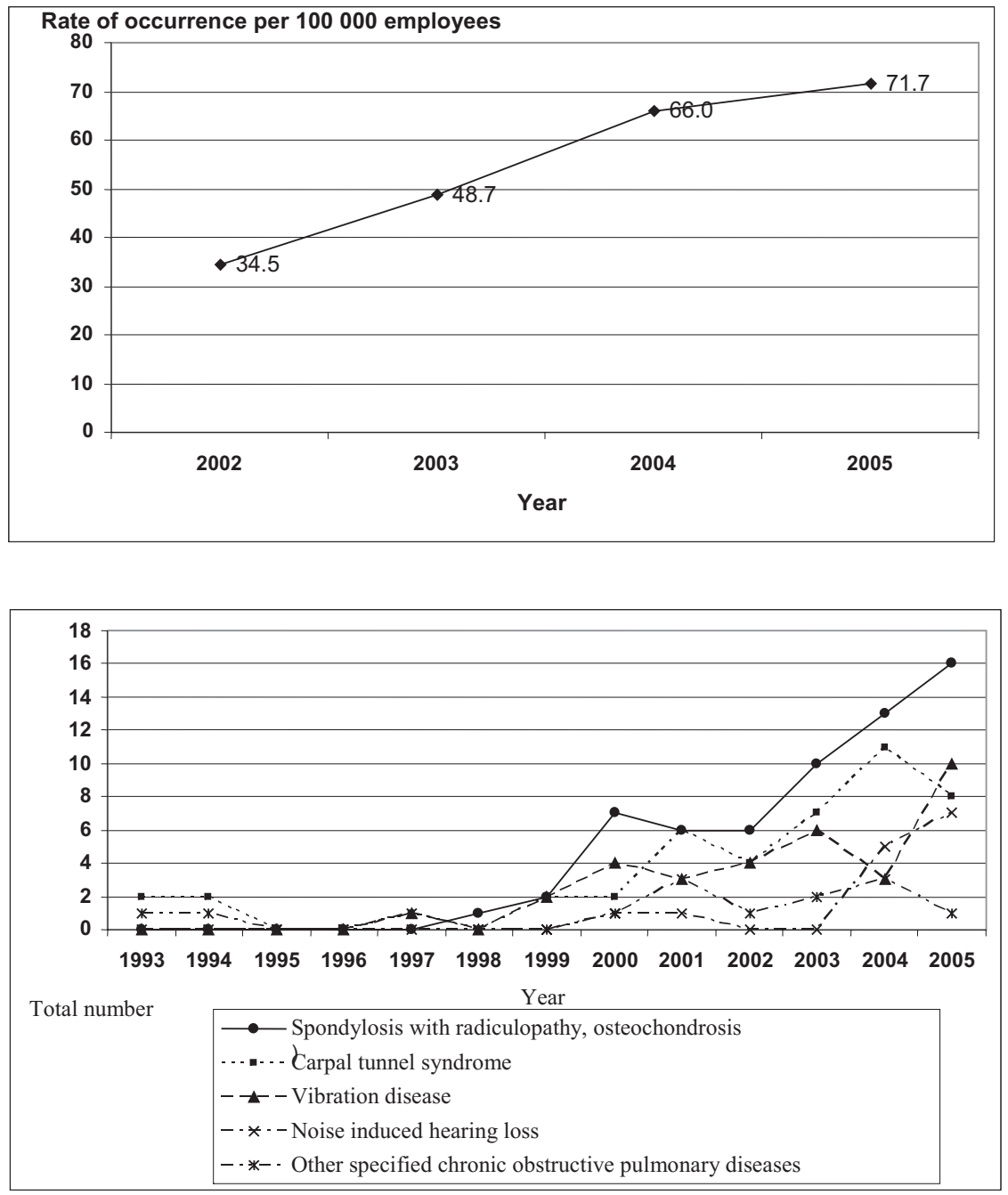

Fig. 1. Dynamics of the number of first-time registered cases of occupational diseases (per $100000 \mathrm{em}-$ ployees) in the industries of wooden, wood and cork production (NACE D20+D36).
Fig. 2. Structure of the most frequent occupational diseases in the wood and cork production industry (D20+D36) (per 100000 employees). 
RATE OF OCCURRENCE OF OCCUPATIONAL DISEASES IN THE MANUFACTURING INDUSTRY PER 100000 EMPLOYEES IN THE PERIOD FROM 2002 TO 2005

\begin{tabular}{|c|c|c|c|c|c|}
\hline Industry & NACE & 2002 & 2003 & 2004 & 2005 \\
\hline Manufacturing industry & $\mathrm{D}$ (total) & 82.2 & 112.4 & 132.2 & 142.7 \\
\hline $\begin{array}{l}\text { Production of wooden, wood and cork products, furniture } \\
\text { manufacturing }\end{array}$ & $\mathrm{D}(20+36)$ & 34.5 & 48.7 & 66.0 & 71.7 \\
\hline $\begin{array}{l}\text { Industry of metals, production of metal goods, manufacturing } \\
\text { of equipments and mechanisms }\end{array}$ & $\mathrm{D}(27+28+29+37.1)$ & 89.0 & 89.5 & 54.3 & 127.4 \\
\hline Production of food products and beverages & D 15 & 62.4 & 116.5 & 145.9 & 126.9 \\
\hline
\end{tabular}

- every third employed patient of a general practitioner has health problems caused by the effects of the working environment (Smedley et al., 2007).

For comparison of illness rate due to occupational diseases in Latvia and abroad, the rate in absolute numbers was calculated per 100000 of employed persons. In 2004, the rate of occurrences of occupational diseases in Latvia was 181.4 cases per 100000 employees, in 2005 - 163.4 cases, and in $2007-142.3$ cases. However, for example, in 2000 , the rate of occurrence of occupational diseases per 100000 employees was 83.6. In comparison with other countries (in 2000, 3.7 cases of occupational diseases diagnosed per 100000 employees in Belarus, 18.1 cases diagnosed per 100000 employees in Russia, 144.1 in Finland, 405.2 cases per 100000 employees in Sweden (Rantanen et al., 2002). In the developed European Union countries, over the last few years, the number of occupational diseases has decreased, while it keeps increasing in Latvia. It can be explained with the fact that the working conditions in the European Union have been improving over the last few decades and correspondingly the number of occupational diseases has been decreasing. However in Latvia, the diagnostics of the occupational diseases is rapidly improving, while improvement of working conditions has started relatively recently. Furthermore, the process has not been rapid, and therefore, positive results can be expected only in future. The situation in Belarus and Russia is presently similar to that of Latvia around the year 1996, when 20.4 occurrences of occupational diseases per 100000 employees were diagnosed. No improvements are being implemented in the field of diagnostics in Belarus and Russia.

The results of our study show that also in the field of wood and cork production, over the last seven years the total rate of occupational diseases has increased, particularly regarding diseases of the musculoskeletal and connective tissue system (spondyloses with radiculopathy) caused by physical overload, as well as occupational hearing problems caused by noise (the rate has increased by more than ten times), and the effects of vibration.

The rapid increase in the number of first-time occupational diseases in Latvia is partially related to the current working conditions. However, it is continuing to be more affected by risk factors of the working environment that had affected the health condition over the last 10-15 years.

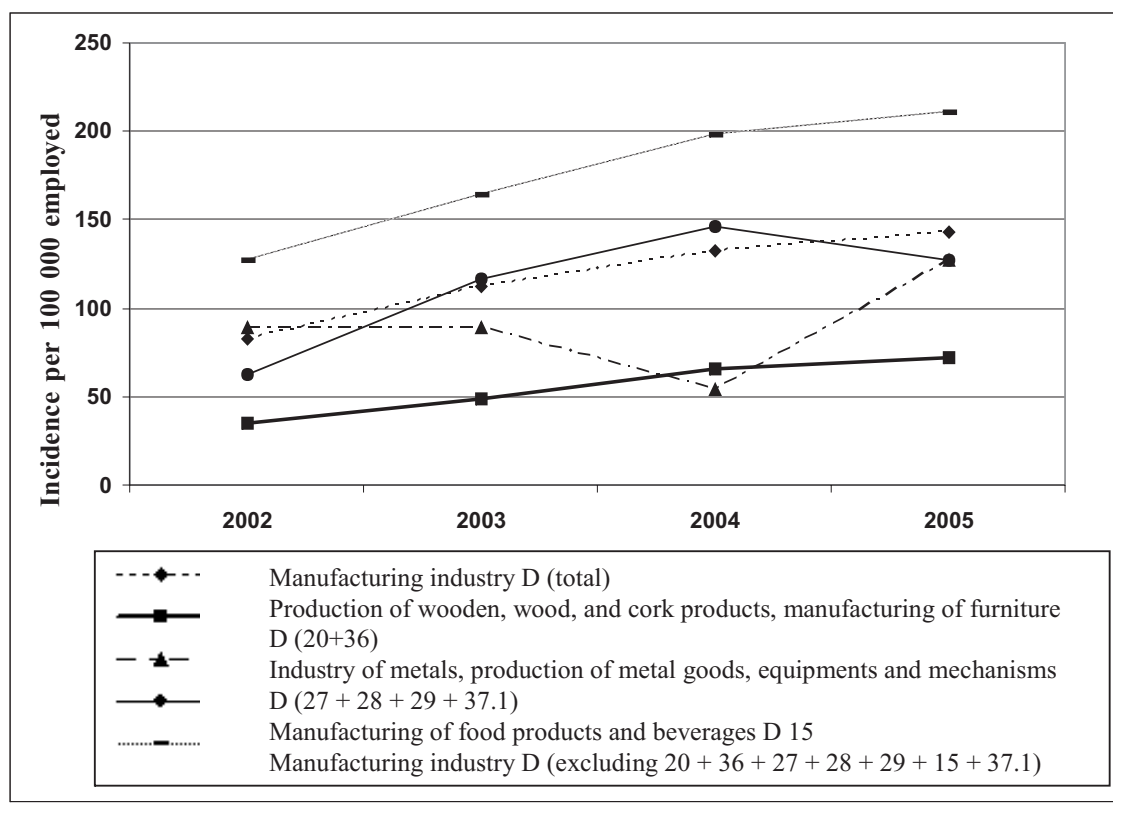

Fig. 3. Rate of occupational diseases per $100000 \mathrm{em}-$ ployees in the manufacturing industry in 2002-2005 (values shown for D20+D36 industries). 
According to the Latvian State Occupational Diseases Patient Registry data in Latvia, many chronic forms of occupational diseases are most common. They have been developing over several years and the time of diagnosing the diseases does not correspond with the time of influence of the risk factors present at the working environment. Therefore, it can be assumed that the increase of the number of occupational diseases is not as much related to the effects of the working conditions, as with other effects, for example:

- over the period of many years, Latvia has shown lower rates of occupational diseases levels than the average in the European Union. Therefore, possibly, diagnostics and records have been improved;

- the employed are becoming more informed about the risk factors of the working environment and symptoms of occupational diseases; more employees are receiving information on the opportunities to receive financial aid in cases of occupational diseases;

- the number of occupational diseases doctors has increased, and most likely, the knowledge level of the doctors has been improved (for instance, duration of training for the doctors of occupational diseases has increased from 50 hours in 1998 to 350 hours in 2009);

- even though the quality of mandatory health checks is still to be assessed as insufficient, although there are no precise data available, the total number of the mandatory health checks has increased.

The decrease in the number of occurrences of first-time diagnoses of occupational diseases in 2005 and 2006 coincided with amendments introduced in the legal requirements - during these years compulsory health examinations were provided also by general practitioners, and not only by occupational physicians. Regulations of the Council of Ministers $(\mathrm{CM})$ on the procedures of performance of mandatory health checks. CM Regulation No. 86, "On mandatory health checks and training in first aid" (adopted on 3 April 1997), established that a conclusion about the health condition of an employee and permit to work in certain work conditions can be issued only by a certified occupational physician. Further, CM Regulation No. 527, "Procedure of performing mandatory health checks" (adopted on 8 June 2004), established that this permit can be issued by a either certified occupational physician or general practitioner). Incompetence of family doctors to solve these matters could be one of the reasons of why the number of the first-time diagnosed occupational diseases decreased in 2005 and 2006 in comparison with 2004.

There is a common opinion that mostly traditional risk factors are present in Latvian companies, such as dust, chemicals, noise and vibration, despite the worldwide change with organizational, psychoemotional and ergonomical risk factors taking over (La Dou, 2007). The survey „Work conditions and risks in Latvia" performed in Latvia during 20052006 showed that also in Latvia psychoemotional factors (shortage of time, long work hours etc.) and ergonomical factors (forced postures, repetitive movements, etc.) are taking the leading role in many industries including woodworking. This compliments the idea that the so-called modern risks are gradually increasing in importance. Despite this trend, traditional factors still have importance (such as noise, chemicals, wood dust and vibration) (Eglite et al., 2002; 2007). These changes in the main risk factors partly explain the changes in occupational morbidity structure.

Our research on morbidity in the wood industry and risk factors correspond with the latest international research on development of chronic respiratory diseases in the woodworking industry, which show dust concentration level as a main factor (Heikkila et al., 2008; Schlunssen et al., 2008; Jacobsen et al., 2009). Chronic irritation of upper and lower respiratory tract can be caused by exposure to wood dust below the European 8-hour exposure limit of $5 \mathrm{mg} / \mathrm{m} 3$ (Veneri et al., 2007). Our measurements indicate that the workers of the wood processing industry are subjected to a significant risk of wood dust in the air of the working environment, which in $38 \%$ of cases exceeds the Latvian occupational exposure limit (OEL) for wood dust $-6 \mathrm{mg} / \mathrm{m}^{3}$.

It is important to diagnose all occupational diseases in a timely manner, because:

- by failing to recognise the real situation, the necessary preventive measures are not implemented in the company and in the country in general, and the employees do not receive any privileges regarding work in special conditions and they are subjected to harmful risk factors;

- occupational diseases patients and people who have suffered in accidents are not receiving the required compensation, as well as compensations for treatment and rehabilitation costs.

The conclusions are:

1. Occupational morbidity in Latvia has gradually increased from 1993 to 2004, with a slight decrease in 2005 and 2006 followed by an increase in 2007. In 2004, the number of first-time occupational diseases patients exceeded the number of occupational diseases patients registered in the year 1993 by 9.5 , and the number of registered first-time cases of occupational diseases in comparison with $1993 \mathrm{had}$ increased by 14.5 times, in association with the improvement of diagnostics and changes in the legislation about compensation in cases of occupational diseases.

2. In the manufacturing industry of wood and cork production, a trend of increasing rate of occupational diseases is observed in Latvia. Over the past four years, a total increase of rate of occupational diseases from 34.5 cases per 100000 employees in 2002 to 71.7 cases per 100000 employees in 2005 was observed. The increase was particularly rapid for illnesses associated with the musculoskeletal and connective tissue system, as well as to occupational hearing loss, which is possibly explained by rapid changes in working conditions. 
3. Despite an increase of the total number of occupational diseases in the wood and cork product industry, over the whole study period, one of the lowest levels of occupational diseases in the country was observed. In 2005, the rate of occupational diseases occurrence in wood and cork production was almost three times lower than that of health and social care, extractive industry and quarry management; 2.5 times lower than in the transportation, transport services, communication and communication sphere, two times lower than the rate in the fishing industry and 1.8 times lower than that in production of food products and beverages and in industry of metals, production of metal goods, manufacturing of equipment and mechanisms.

4. In developed European Union countries, over the last few years, the number of occupational diseases has decreased, while it has increased in Latvia. This can be explained by the fact that the working conditions in the European Union have been improving over the last few decades. In Latvia, the diagnostics of the occupational diseases is rapidly improving, while improvement of working conditions has started relatively recently. Furthermore, the process has not been as rapid, and therefore, the results can be expected only in the future.

\section{REFERENCES}

Eglite, M., Vanadzins, I., Matisane, L. Basic information on Latvia and its health system. In: People and Work. Research report 52 (pp. 239-256). Rantanen, J., Kauppinen, T., Lehtinen, S., Matill., M., Toikkanen, J., Kurppa, K., Lino, T. (eds.). Helsinki: Finnish Institute of Occupational Health.

Eglite, M., Matisāne, L., Vanadziņš, I., Antonovica, R., Baķe, M., Boriskins, A., Drukis, P., Dumbrovska, S., Grīnberga, S., Mangule, R., Martinsone, Z., Mārtiņsone I., Piḳe, A., Reste, R., Sprūdža, D., Sudmalis, P. (2007). Work Conditions and Risks in Latvia. Rīga: RL Ministry of Welfare. 146 pp.

Heikkil, P., Martikainen, R., Kurppa, K., Husgafvel-Pursiainen, K., Karjalainen, A. (2008). Asthma incidence in wood-processing industries in Finland in a register-based population study. Scand. J. Work Environ. Health., 34(1), 66-72.

Innos, K., Rahu, M., Rahu, K., Lang, I., Leon, D. (2000). Wood dust exposure and cancer incidence: Retrospective cohort study of furniture workers industry in Estonia. Amer. J. Ind. Med., 37, 501-511.
Jacobsen, G., Schlunssen, V., Schaumburg, I., Sigsgaard, T. (2009). Increased incidence of respiratory symptoms among female woodworkers exposed to dry wood. Eur. Respir. J, 33(6), 1268-1276.

Kaḷkis, V., Roja, Ž. (2000). Darba vides riska faktori un strādājošo veselības aizsardzība [Work Environment Risk Factors and Health Protection of the Employees]. Rīga: Elpa, 500 lpp. (359.-370. lpp.) (in Latvian).

Kauppinen, T., Vincent, R., Liukkonen, T., Grzebyk M., Kauppinen A., Welling I., Arezes P., Black N., Bochmann F., Campelo, F., Costa, M., Elsigan, G., Goerens, R., Kikemenis, A., Kromhout, H., Miguel, S., Mirabelli, D., McEneany, R., Pesch, B., Plato, N., Schlünssen, V., Schulze, J., Sonntag, R., Verougstraete, V., De Vicente M.A., Wolf, J., Zimmermann,, M., Husgafvel-Pursiainen, K., Savolainen, K. (2006). Occupational exposure to inhalable wood dust in the member states of the European Union. Ann. Occup. Hyg., 50, 549-561.

La Dou, J. (ed.). (2007). Current Occupational and Environmental Medicine. $4^{\text {th }}$ edition. New York: Mc Graw Hill Medical. 846 pp.

Mandryk, J., Alwais, K.U., Hocking, A.D. (2000). Effects of personal exposures on pulmonary function and work-related symptoms among sawmill workers. Ann. Occup. Hyg., 44, 281-289.

Martinsone, Ž., Vanadziņš, I., Sprūdža, D., Eglīte, M., Baķe, M.Ā., Sudmalis, P., Piķe, A., Mārtiņsone, I., Reste, J., Dumbrovska, S. (2006). Kokapstrādes un mēbeḷu ražošanas nozarē esošo riska faktoru un arodslimību dinamikas analīze Latvijā laika posmā no 1998. līdz 2005. gadam [Analysis of the dynamics of risk factors and occupational diseases of wood-processing and furniture production industry employees in Latvia in 1998-2005]. Grām.: RSU Zinātniskie raksti (206.-213. lpp.). Rīga: RSU.

Mikkelson, A., Schlunssen, V., Sigsgaard, T. (2002). Determinants of wood dust exsposure in the Danish furniture industry. Ann. Ocup. Hyg., 46, 673-685.

Priha, E., Pennanen, S., Ratio, T. (2004) Exposure to and acute effects of medium-density fiber board dust. J. Occup Environ Hyg., 1(11), 738-744.

Smedley, J., Dick, F., Sadhra, S. (eds.). (2007). Oxford Handbook of Occupational Health. Oxford: University Press. 932 pp.

Schlunssen, V., Jacobsen, G., Erlandsen, M., Mikkelsen, A.B., Schaumburg, I., Sigsgaard, T. (2008). Determinations of wood dust exposure in the Danish furniture industry - results from two cross-sectional studies 6 years apart. Ann. Occup. Hyg., 52, 227-238.

Vanadziņš, I., Baķe, M.Ā., Sprūdža, D., Lūse, I., Linņika, Ž. (2003). Riska faktoru izpēte finiera ražošanā nodarbinātajiem [Analysis of risk factors of employees of woodworking industry]. RSU Zinātniskie raksti. Rīga: RSU, 366.-371. lpp. (in Latvian).

Veneri, L., Caso, M.A., Ravaioli, M., Albonetti, A., Ghini, P., Mazzavillani, M., Valentini, M.G. (2007). Study on prevalence of upper and lower airways disorders in woodworkers, using data from medical surveillance reports and exposure registers. G. Ital. Med. Lav. Ergon., 29(3 Suppl.), $833-835$.

Received 19 February 2009

\section{ARODSASLIMSTĪBAS IZPĒTE KOKAPSTRĀDĒ NODARBINĀTAJIEM SALĪDZINĀJUMĀ AR CITĀM RAŽOŠANAS NOZARĒM UN VISPĀRĒJO ARODSASLIMSTIIBU LATVIJĀ}

Darba mērkis — izpētīt arodsaslimstību kokapstrādes nozarē, lai saprastu reālo situāciju nozares arodveselībā un uzlabotu arodslimību diagnostiku. Pirmreizēji diagnosticēto un no jauna reǵistrēto arodslimnieku un arī arodslimību gadījumu skaits Latvijā pakāpeniski pieaudzis no 1993. gada līdz 2004. gadam. 2005. gadā konstatēta neliela reǵistrēto arodslimnieku un arodslimību skaita samazināšanās, kas turpinājās arī 2006. gadā, bet 2007. gadā atkal novērojams pirmreizēji reǵistrēto arodslimnieku un arodslimību gadījumu skaita pieaugums, tomēr nesasniedzot 2004. gada līmeni. 2004. gadā pirmreizēji diagnosticēto arodslimnieku skaits 9,5 reizes pārsniedza 1993. gadā reǵistrēto arodslimnieku skaitu, bet pirmreizēji reǵistrēto arodslimību skaits, salīdzinot ar 1993. gadu, 2004. gadā pieaudzis 14,5 reizes. Neraugoties uz arodsaslimstības palielināšanos Latvijā, tā tomēr ir zemāka nekā attīstītajās Eiropas valstīs. Arodslimību struktūrā gan Latvijā vispār, gan kokapstrādē pieaug muskuḷu, skeleta un saistaudu sistēmas slimību un karpālā kanāla sindroma gadījumu skaits, kā arī aroda etioloğijas dzirdes pavājināšanās, ko var izskaidrot ar izmaiņām darba vides riska faktoros. Neraugoties uz kopējo arodslimību skaita pieaugumu kokapstrādes un mēbeḷu ražošanas nozarē, visā pētījuma periodā arodsaslimstība šajā nozarē ir viena no zemākajām valstī salīdzinājumā ar citām nozarēm, piemēram, veselības un sociālo aprūpi, ieguves un karjeru rūpniecību, transportu un tā pakalpojumu, komunikācijas sfēru, metālapstrādi, zvejniecību. 